\title{
Is There Any Relation of Urine Leukocytes with Dimple on the Chin?
}

\author{
Muhammad Imran Qadir and Noor Arif* \\ Institute of Molecular Biology and Biotechnology, Pakistan
}

*Corresponding author: Noor Arif, Institute of Molecular Biology and Biotechnology, Bahauddin Zakariya University, Multan, Pakistan

\begin{tabular}{|c|c|}
\hline ARTICLE INFO & ABSTRACT \\
\hline Received: 慧 September 26, 2019 & \multirow{7}{*}{$\begin{array}{l}\text { Leukocytes also called as WBCs and they are the part of the immune system of } \\
\text { the body. Urine contains very minimal number of leukocytes. High concentration of } \\
\text { these WBCs in the urine be a sign of an infection. Chin dimple is a vertical shaped or Y } \\
\text { shaped fissure on the chin that is called as chin dimple. This is the heritable trait that is } \\
\text { passed from parents to offspring. This dimple is differed from the cleft as dimple is less } \\
\text { prominent on the chin as compared to the cleft. Objective of this study was to correlate } \\
\text { the dimple on the chin with the urine leukocytes. A total of } 100 \text { subjects participated in } \\
\text { this research that were undergraduate students in BZU, Multan, Pakistan. Relation of } \\
\text { urine leukocytes with dimple on the chin was observed. Urinalysis was done to check the } \\
\text { presence of urine leukocytes. Dipstick test was performed in the lab. It was concluded } \\
\text { from the study that male with presence of chin dimple has absence of urine leukocytes } \\
\text { so there is no relation between them. }\end{array}$} \\
\hline Published: 慧 October 11, 2019 & \\
\hline Citation: Muhammad Imran Qadir, Noor & \\
\hline Arif. Is There Any Relation of Urine & \\
\hline Leukocytes with Dimple on the Chin?. & \\
\hline $\begin{array}{l}\text { Biomed J Sci \& Tech Res 21(5)-2019. } \\
\text { BJSTR. MS.ID.003671. }\end{array}$ & \\
\hline $\begin{array}{l}\text { Keywords: Urine Leukocytes; Dimple on } \\
\text { the Chin; WBCs }\end{array}$ & \\
\hline
\end{tabular}

\section{Introduction}

Leukocytes also called as WBCs and they are the part of the immune system of the body. Foreign substances when enters the body, WBCs act against them and kill them. These cells by produced and stored by different parts of the body such as spleen, nodes of lymph and bone marrow. These leukocytes move throughout the body to check any infectious microbes present in the body. Urine contains very minimal number of leukocytes. High concentration of these WBCs in the urine be a sign of an infection. Leukocytes can occur in the urine due to various causes. One of them is the bladder infections. Infection of the urinary tract is the reason of leukocytes in urine. This infection happens when the bacteria such as E. coli enters the body and infects the urethra of the body. This disease mostly occurs in the women. If this infection is not properly treated on time, then it can spread to the other parts of the body and leads to the serious complications. Other reason of elevated level of leukocytes is the presence of kidney stones. High level of minerals and salts leads to the formation of the kidney stones. Symptoms include pain, vomiting, fever, cold. Kidney infection is also the cause of increase of white blood cells in the body. The infections often start through the urinary tract, but it spreads in the kidney leading to serious complications. Kidney infection is often due to the weak immune systems because the immune system is unable to fight against the bacteria that enters the body, so it leads to the infection in the body. Holding the urine for long time is also the cause of elevated level of leukocytes in the urine. Accumulation of urine causes the infection of the kidney [1-7]. Chin dimple is a vertical shaped or Y shaped fissure on the chin that is called as chin dimple. This is the heritable trait that is passed from parents to offspring. This dimple is differed from the cleft as dimple is less prominent on the chin as compared to the cleft which is more prominent on the chin. This dimple is considered as the beauty factor in some people.

The vast majority consider that split in jawline and jaw dimple are indistinguishable yet there is an irrelevant contrast in them. Separated is more obvious than jaw dimple so the general population having split are additionally appealing. Ladies having jawline dimple have the initiative forces and they can adapt to the obscurities with no trouble. Men having jawline dimple are eager, nervy and yearning. Objective of this study was to correlate the dimple on the chin with the urine leukocytes. 


\section{Materials and Methods}

\section{Measurement of Urine Leukocytes}

Urinalysis is the method to screen the urine to detect any problems. For this, urine sample was collected in the container and Dipstick test was done. A strip was dipped in the sample for 2 to 3 seconds and then after the appearance of colors on the strip, it was matched with the chart present on the bottle and note down the results.

\section{Task Design}

A total of 100 subjects participated in this research that were undergraduate students in BZU, Multan, Pakistan. Relation of urine leukocytes with dimple on the chin was observed.

\section{Statistical Analysis}

Statistical analysis was performed by using MS Excel.

\section{Results}

Relation of chin dimple with leukocytes in urine is given in (Tables 1\&2). In Table 1, normal value of urine leukocytes was more in people who had absence of chin dimple while in Table 2, positive value of urine leukocytes was more in male with presence of chin dimple and in females with absence of chin dimple in them. The (Figure 1) shows the relation of positive value of urine leukocytes with dimple on the chin. All males have presence of dimple on the chin as there is more ratio among males. While the females have more ratio of absence of dimple on the chin.

Table 1: Relation of urine leukocytes with chin dimple.

\begin{tabular}{|c|c|c|c|c|}
\hline \multirow{2}{*}{$\begin{array}{c}\text { Chin } \\
\text { Dimple }\end{array}$} & \multicolumn{3}{|c|}{ Urine Leukocytes Positive } & $\begin{array}{c}\text { Urine Leukocytes } \\
\text { Negative }\end{array}$ \\
\hline \multirow{2}{*}{ Presence } & 25 & 50 & 75 & -ve (0) Normal \\
\cline { 2 - 5 } & $0 \%$ & $2 \%$ & $1 \%$ & $18 \%$ \\
\hline Absence & $2 \%$ & $1 \%$ & $6 \%$ & $70 \%$ \\
\hline
\end{tabular}

Table 2: Relation of positive value of urine leukocytes with dimple on the chin.

\begin{tabular}{|c|c|c|}
\hline Chin Dimple & Presence of Chin Dimple & Absence of Chin Dimple \\
\hline Male & $100 \%$ & $0 \%$ \\
\hline Female & $18 \%$ & $82 \%$ \\
\hline
\end{tabular}

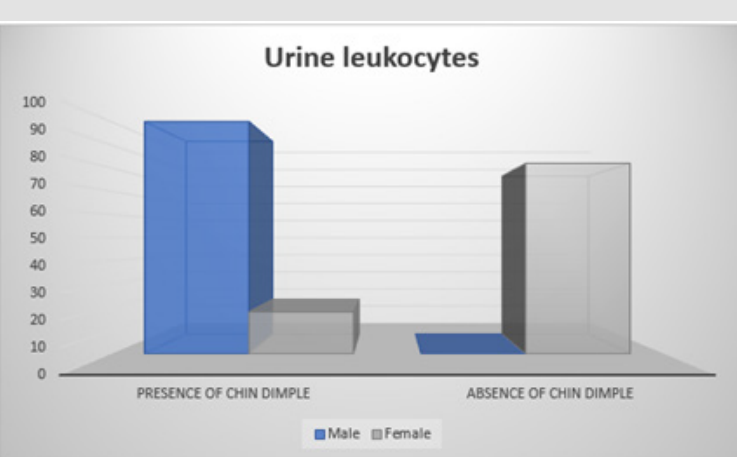

Figure 1: Relation of dimple on the chin with urine leukocytes.

\section{Discussion}

Mcmenamy, C. Lund, Neville and few others did a study on the amino acid level in blood plasma, leukocytes present in the body and urine. They measured the concentration of unbound amino acid in different blood contents. They present different methods for the measurement of concentration of unbound amino acids. Gillenwater did another study on the detection of urine leukocytes by chemstrip. This chemstrip reacts with esterases that are present in the urine with leukocytes, but it did not react with the normal urine, this chemstrip has $98 \%$ specificity. Another study was done by E. C. Boer, W. H. Jong, or other on the leukocytes in the urine after the BCG treatment [8-12]. They observed that Cell immunologic responses happening in the bladder after intravesical treatment with Bacillus Calmette-Guérin (BCG) were explored by stream cytofluorometric investigation of leukocytes present in the pee. Pee examples from 11 shallow bladder disease patients were gathered previously.

T-and B-lymphocytes were utilized to describe and measure leukocyte subpopulations. The prevalent cell type present was the polymorphonuclear granulocyte, most likely speaking to a guard system against mycobacteria. Despite the fact that rates of lymphocytes were low, T-and B-cells could be distinguished utilizing a specific cell estimation system. All in all, an unmistakable increment in the quantities of granulocytes, monocytes/ macrophages and T-lymphocytes in pee after intravesical BCG organization was illustrated, demonstrating nearby enactment of the resistant framework.

\section{Conclusion}

It was concluded from the study that male with presence of chin dimple has absence of urine leukocytes so there is no relation between them.

\section{References}

1. Boo Chai K (1962) The facial dimple-Clinical study and operative technique. Plastic and Reconstructive Surgery 30(2): 281-288.

2. Daponte AP, Vienna A, Brant L, Hauser G (2004) Cheek dimples in Greek children and adolescents. International Journal of Anthropology 19(4): 289-295.

3. Qadir MI, Javid A (2018) Awareness about Crohn's Disease in biotechnology students. Glo Adv Res J Med Medical Sci 7(3): 62-64.

4. Qadir MI, Saleem A (2018) Awareness about ischemic heart disease in university biotechnology students. Glo Adv Res J Med Medical Sci 7(3): 59-61.

5. Qadir MI, Ishfaq S (2018) Awareness about hypertension in biology students. Int J Mod Pharma Res 7(2): 08-10.

6. Qadir MI, Mehwish (2018) Awareness about psoriasis disease. Int J Mod Pharma Res 7(2): 17-18.

7. Qadir MI, Shahzad R (2018) Awareness about obesity in postgraduate students of biotechnology. Int J Mod Pharma Res 7(2): 14-16.

8. Qadir MI, Rizvi M (2018) Awareness about thalassemia in post graduate students. MOJ Lymphology Phlebology 2(1): 14-16.

9. Qadir MI, Ghalia BA (2018) Awareness survey about colorectal cancer in students of M. Phil Biotechnology at Bahauddin Zakariya University, Multan, Pakistan. Nov Appro in Can Study 1(3). 
10. Qadir MI, Saba G (2018) Awareness about intestinal cancer in university student. Nov Appro in Can Study 1(3).

11. McMENAMY RH, Lund CC, Neville GJ, Wallach DF (1960) Studies of unbound amino acid distributions in plasma, erythrocytes, leukocytes and urine of normal human subjects. The Journal of clinical investigation 39(11): 1675-1687.

ISSN: 2574-1241

DOI: 10.26717/BJSTR.2019.21.003671

Noor Arif. Biomed J Sci \& Tech Res

(C) (i) This work is licensed under Creative

Submission Link: https://biomedres.us/submit-manuscript.php
12. De Boer EC, De Jong WH, Van der Meijden AP, Steerenberg PA, Witjes F, et al. (1991) Leukocytes in the urine after intravesical BCG treatment for superficial bladder cancer. Urological research 19(1): 45-50.

$\begin{array}{ll}\text { BIOMEDICAL } & \text { Assets of Publishing with us } \\ \text { RESEARCHES } & \text { - Global archiving of articles } \\ & \text { - Immediate, unrestricted online access } \\ \end{array}$

